\title{
PENERAPAN MODEL DELIKAN \\ SEBAGAI UPAYA PENINGKATAN KUALITAS PEMBELAJARAN \\ IPS-SEJARAH DI SMP MUHAMMADIYAH IV \\ YOGYAKARTA
}

Oleh

Aman, Grendi Hendrastomo, Sudrajat. ${ }^{1}$

\begin{abstract}
For students at Junior High School, the subject of social studies is very bored to be heared. Learning method is one of several factors that cause these problem. The goal of our research is to apply the delikan method to improve the quality of social studies learning at Junior High School.

This class action research uses recommendation from Kurt Lewin models involving a spiral of cycles: initial idea, reconnaissance (fact finding), general plan, implement, and evaluate. We implements two cycles in which paper in first cycles and comic in second cycles. Delikan is a learning method involves hear (de), see (li), and done (kan). For implement this method we divide class on eight groups. For each groups, we give one theme for their task.

From our research, we conclude that implementation of Delikan method lead improvement on social studies subject at Junior High School level. We have four parameters indicating the fenomenon. First, students have done the task with happy. They have a pleasant time to improve their ability to write and draw. Second, students enjoy work together in group collaboration with their classmate. This method can improve social relations between the students. Third, this method can exploit another student's competencies, for example: write, draw etc. Finally, delikan motivate students to further learn with read another sources: book, magazine, internet, etc.
\end{abstract}

Keyword: delikan, social studies, method of learning.

\section{A. Pendahuluan}

Salah satu faktor penyebab keterpurukan bangsa Indonesia saat ini adalah rendahnya kualitas pendidikan nasional. Bila dibandingkan dengan negara-negara tetangga, pendidikan di Indonesia masih jauh tertinggal. Kalau pada era 1970-an Malaysia merupakan salah satu anak didik kita, namun sekarang kita harus belajar banyak dari mantan anak didik kita tersebut. Salah satu faktor penyebab keterpurukan pendidikan di Indonesia barangkali

${ }^{1}$ Dosen pada Jurusan Pendidikan Sejarah, Fakultas Ilmu Sosial dan Ekonomi Universitas Negeri Yogyakarta. 
disebabkan oleh adanya politisasi dunia pendidikan, sehingga pendekatan yang dipergunakan serba instan dan hanya sekadar kebijakan tambal sulam yang tidak akan menyelesaikan permasalahan secara fundamental. Salah satu contoh adalah tidak dipenuhinya tuntutan UUD 1945 yang mengamanatkan anggaran pendidikan sebesar 20\% dari APBN. Akibatnya banyak sekali sekolah yang tidak layak pakai, rendahnya kesejahteraan guru dan tenaga kependidikan, rendahnya kualitas guru, dan lain-lain.

Rendahnya kualitas dan kesejahteraan guru merupakan inti dari permasalahan pendidikan di Indonesia. Kondisi yang demikian menyebabkan mereka tidak optimal dalam menjalankan tugasnya. Mengajar merupakan suatu aktivitas yang memerlukan ketrampilan tingkat tinggi dan mencakup hal-hal yang berkaitan dengan pengambilan keputusan. ${ }^{2}$ Sekarang ini guru dituntut untuk berperan sebagai pengelola proses belajar mengajar. Keberhasilan proses belajar mengajar sangat tergantung pada kemampuan guru dalam membuat perencanaan pembelajaran, yang menyangkut antara lain menentukan tujuan pembelajaran, bagaimana cara dan metode yang akan digunakan untuk mencapai tujuan yang telah ditetapkan itu. Sementara itu dalam kaitannya dengan mengatur proses pembelajaran, guru juga dituntut untuk menentukan bagaimana caranya memberikan motivasi kepada peserta didik, memilih alat, media, dan sarana yang akan dipergunakan dalam proses pembelajaran dan lain-lain. Mengingat pentingnya hal tersebut, maka tidak mengherankan apabila guru mendapat ekspektasi yang cukup signifikan dalam upaya peningkatan pendidikan nasional.

Terkait dengan proses pembelajaran di sekolah, maka IPS-Sejarah merupakan salah satu mata pelajaran yang perlu mandapat perhatian dari semua pihak khususnya pakar dan pemerhati masalah pendidikan. Sebagai dampak dari diberlakukannya IPS Terpadu, maka IPS-Sejarah merupakan salah satu bagian dari keterpaduan IPS, di samping mata pelajaran lainnya seperti IPS-Geografi dan IPS-Ekonomi. Sampai sekarang format dan kurikulum yang telah dipergunakan masih terus mengalami penyempurnaan sehingga mata pelajaran yang satu ini perlu mendapat perhatian yang lebih serius.

Di luar hal-hal tersebut, metode pembelajaran IPS merupakan permasalahan yang perlu mendapat perhatian. Sudah jamak diketahui oleh semua kalangan bahwa salah satu kelemahan metode pembelajaran IPS adalah adanya

2 Winata Putera (1992), Model-model Pembelajaran, Jakarta: Depdikbud. Hlm. 86. 
penjejalan materi sehingga pembelajaran menjadi kurang bermakna bagi siswa. Pembelajaran yang bersifat kognitif ini harus perlahan-lahan diubah sehingga aspek afektif dan psikomotor juga mendapat porsi yang seimbang. Permasalahannya adalah apakah ada metode yang tepat untuk mencapai pembelajaran yang demikian itu? Tidak mudah untuk menjawab pertanyaan yang demikian, karena memang tidak ditemukan metode yang paling tepat untuk mengajarkan IPS-Sejarah. Oleh karena itu guru harus mampu berimprovisasi dengan suasana dan fasilitas yang dimiliki oleh sekolah. Dalam kaitan dengan hal tersebut, Delikan merupakan salah satu model pembelajaran yang perlu dicoba untuk diterapkan dalam proses pembelajaran.

\section{B. Delikan Sebagai Model Pembelajaran}

Delikan merupakan akronim dari dengar (de), lihat (li), dan kerjakan (kan). Model ini diangkat dan dikembangkan atas dasar pengalaman empiris di lapangan, artinya merupakan pengkajian dari hasil pengamatan terhadap praktek mengajar para guru di sekolah, terutama kaitannya dengan upaya untuk mengaktifkan siswa dalam proses pembelajaran. ${ }^{3}$ Pada awalnya model ini dikembangkan di sekolah dasar, namun pada perkembangannya model tersebut juga dapat diterapkan pada pembelajaran untuk tingkat SMP maupun SMA.

Sebagai sebuah model pembelajaran, delikan harus dipandang secara holistik dan berkesinambungan. Dalam hal ini proses dengar dibarengi oleh proses lihat dan proses kerja. ${ }^{4}$ Dengan demikian maka pembelajaran akan memberikan kesan yang mendalam dan bermakna karena ditangkap oleh tiga indera yaitu penglihatan, pendengaran, dan tentunya juga indera motorik. Aspek yang dikembangkan dalam pembelajaran dengan model delikan antara lain: kognitif (dalam proses mendengar dan melihat), afektif, dan psikomotor. Beberapa keuntungan yang dapat diperoleh dengan diterapkannya model delikan antara lain:

1. Materi pembelajaran lebih bermakna bagi siswa;

2. Mendorong siswa untuk belajar lebih lanjut;

3. Memori siswa bertahan lebih lama.

Penyelidikan dari para ahli ilmu jiwa membuktikan dengan tegas bahwa berhasil tidaknya belajar tergantung pada makna dari apa yang dipelajari.

${ }^{3}$ Sri Anitah Wiryawan \& Nurhadi (2001), Strategi Belajar Mengajar, Jakarta: Pusat Penerbitan Universitas Terbuka. Hlm. 270.

${ }^{4}$ Ibid. 
Pelajaran itu bermakna sejauh pelajaran atau masalah itu riil atau berharga bagi si pelajar, dan sejauh hubungan esensial antara bagian-bagiannya ditegaskan, sehingga murid adalah menangkap atau memahami hubungan-hubungan dalam keseluruhan itu. ${ }^{5}$

Model delikan merupakan suatu strategi pembelajaran yang memungkinkan peserta didik mendapatkan jawabannya sendiri. ${ }^{6}$ Ini merupakan sebuah model pembelajaran yang penyampaian bahan pelajarannya tidak berbentuk final, tidak langsung. Artinya dalam penyampaian materi peserta didik diberi kesempatan untuk mencari dan memecahkan sendiri permasalahannya dengan mempergunakan teknik pemecahan masalah.

Sementara itu pengajar bertindak sebagai pengarah, mediator dan fasilitator yang wajib memberika informasi yang relevan dengan permasalahan atau materi pelajaran. Hal ini dapat dilakukan di dalam kelompok-kelompok kecil di dalam kelas melalui diskusi dan bermain peran. Dalam kegiatan ini peserta didik dituntut untuk aktif dan terlibat dalam situasi belajar. Peserta didik menyadari adaya masalah, mengajukan pertanyaan, selanjutnya menghimpun informasi sebelum mengambil keputusan. ${ }^{7}$ Model delikan diterapkan dengan enam tahap pelaksanaan yang meliputi:

1. Tahap orientasi berupa kegiatan menetapkan masalah sebagai pokok bahasan yang akan dirumuskan dalam bentuk pertanyaan.

2. Tahap hipotesis yaitu merumuskan hipotesis sebagai acuan dalam delikan.

3. Tahap definisi yaitu menguraikan dan memperjelas hipotesis.

4. Tahap eksploratif berupa pengujian hipotesis menurut logika yang disesuai dengan implikasi dan asumsi

5. Tahap pembuktian yaitu mengumpulkan data dan fakta untuk membuktikan hipotesis,

6. Tahap generalisasi yaitu membuat kesimpulan sebagai pemecahan atau jawaban permasalahan yang dapat diterima kebenarannya.

\section{Konsep Dasar IPS}

Istilah ilmu pengetahuan sosial (IPS) merupakan terjemahan dari social studies yang diterapkan di Amerika Serikat. Perkembangan social studies di

${ }^{5}$ Nasution, (2002), Mengajar Dengan Sukses, Yogyakarta: Bumi Aksara. Hlm. 20.

${ }^{6}$ Soewarso (2000), Cara Penyampaian Pendidikan Sejarah Untuk Membangkitkan Minat Peserta Didik Mempelajari Sejarah Bangsanya, Jakarta: Dirjen Dikti Depdiknas. Hlm. 57.

${ }^{7}$ Ibid. 
Amerika Serikat terkait erat dengan adanya kebutuhan integrasi nasional akibat membajirnya imigran dari Eropa Selatan yang dikhawatirkan dapat mengacaukan perkembangan peradaban Anglo-Saxon. Sementara itu mata pelajaran sejarah, geografi, dan civics yang diajarkan secara terpisah dianggap tidak mampu mencapai tujuan nasional Amerika Serikat. Oleh karena itu pada tahun 1916 Wesley, mengusulkan perlunya penggabungan mata pelajaran sejarah, geografi dan civics menjadi mata pelajaran IPS. Wesley merumuskan social studies sebagai: the simplified for pedagogical purpose ... in school the social studies usually consist of geography, history, economics, sociology and civics, and various combination of these subjects. ${ }^{8}$

Definisi social studies mengalami perkembangan dengan hadirnya National Council for Social Studies (NCSS) yang memberikan definisi bahwa social studies sebagai the integrated study of the social sciences and humanities to promote civics competence. Penekanan pada kewarganegaraan disebabkan oleh adanya upaya untuk mempersiapkan warga negara untuk dapat hidup dalam negara demokrasi.

Di Indonesia, latar belakang munculnya IPS terkait erat dengan pembangunan nasional dan integrasi nasional (national development and national integration). Hal ini diatasi dengan diperkenalkannya pendidikan civics yang pada perkembangannya menjadi Pendidikan Moral Pancasila (PMP). Terakhir kali berdasarkan Peraturan Menteri Pendidikan Nasional No. 22 tahun 2006, Pendidikan Moral Pancasila diganti menjadi Pendidikan Kewarganegaraan yang disingkat Pkn. Pada perkembangannya masalah sosial yang muncul sebagai dampak pembangunan nasional memerlukan sebuah pelajaran yang tidak semata-mata pada pembentukan watak dan karakter warga negara, namun juga perlu adanya penekanan pada wawasan sosial yang lebih luas. Oleh karena itu ilmu pengetahuan sosial merupakan solusi untuk mengatasi masalah kerawanan sosial sebagai dampak pembangunan nasional. Melalui IPS siswa diajarkan untuk memahami kenyataan masyarakat dengan berbagai permasalahannya.

Di Indonesia IPS didefinisikan sebagai penyederhanaan, adaptasi, seleksi, dan modifikasi dari disiplin akademis ilmu-ilmu sosial yang diorganisir dan disajikan secara ilmiah dan pedagogis yang diperkenalkan di sekolah dasar dan menengah dalam rangkan mewujudkan tujuan pendidikan nasional yang

${ }^{8}$ Ibid. 
berdasarkan Pancasila. Sementara Daldjoeni memberikan pengertian IPS sebagai pelajaran ilmu-ilmu sosial yang disederhanakan untuk pendidikan tingkat SD, SMP dan SMA. ${ }^{9}$ Hakekat IPS merupakan pengetahuan yang mengkaji hubungan antar manusia dengan lingkungannya, baik lingkungan fisik maupun sosial dengan menggunakan ilmu politik, ekonomi, sejarah, geografi, sosiologi, antropologi, dan hukum.

\section{Hakekat Pembelajaran IPS-Sejarah}

Pembelajaran sejarah sebagai subsistem dari kegiatan pendidikan merupakan sarana yang efektif untuk meningkatkan kualitas dan integritas bangsa melalui proses pembelajaran. Sistem pendidikan dan pengajaran merupakan sistem yang kompleks diletakkan sebagai usaha bersama untuk memenuhi kebutuhan pendidikan dalam rangka membangun dan mengembangkan diri. ${ }^{10}$ Dalam pengajaran sejarah masih banyak hal yang memerlukan pembenahan agar sejarah dapat berperan optimal dalam pembentukan watak bangsa (nation and character building). Dengan demikian pengajaran sejarah tidak lagi menitikberatkan pada pencapaian ranah kognitif, tetapi harus mulai menyentuh ranah afektif dan psikomotor. Dalam hal ini sebenarnya sejarah dapat berperan dengan baik karena pelajaran ini dapat menumbuhkan semangat nasionalisme. Pembelajaran sejarah yang menekankan fakta-fakta keras perlu mendapatkan perhatian karena hanya akan menimbulkan rasa bosan di kalangan peserta didik dan pada gilirannya nanti akan menimbulkan keengganan untuk belajar sejarah di kalangan generasi muda. ${ }^{11}$

Lebih lanjut, Dennis Gunning menambahkan bahwa pembelajaran sejarah bertujuan untuk membentuk warga negara yang baik. Di samping itu sejarah juga menyadarkan peserta didik untuk mengenal diri dan lingkungannya serta memberikan perspektif historis. Secara spesifik tujuan pembelajaran sejarah ada tiga: mengajarkan konsep, mengajarkan ketrampilan intelektual, dan memberikan informasi kepada peserta didik. ${ }^{12}$ Dalam hal ini pembelajaran sejarah tidak lagi sekadar menghafal pelbagai peristiwa dengan angka tahun dan tempat-tempat terjadinya persitiwa tersebut. Namun

${ }^{9}$ Ibid.

${ }^{10}$ Banathy, Bella H (1992), A System View of Education: Concepts and Principles for Effective Practice, Englewood Cliffs: Educational Technology Publication. Hlm. 175.

${ }^{11}$ Soedjatmoko (1976), "Kesadaran Sejarah Dalam Pembangunan”, Prisma Edisi VII. Hlm. 15.

${ }^{12}$ Gunning, Dennis (1978), The Teaching of History, London: Cronhelm. Hlm. 179. 
pembelajaran sejarah diarahkan pada pembentukan karakter melalui aktualisasi diri dan kesadaran akan adanya kebersamaan dalam keberagaman sehingga peserta didik ikut serta menentukan masa depan yang lebih manusiawi. Menurut Preire yang terpenting adalah pendidikan harus berorientasi pada pengenalan realitas diri manusia dan dirinya sendiri. ${ }^{13}$

Pada sisi yang lain, tujuan pembelajaran sejarah harus melalui proses dimana guru dan peserta didik melakukan riset bersama. Dengan jalan demikian maka peserta didik dihadapkan dengan tantangan intelektual sehingga terbentuklah sebuah adventure antara pendidik dan peserta didik. ${ }^{14}$

Pada akhirnya pembelajaran sejarah memerlukan strategi dan metode baru untuk membentuk image pelajaran yang lebih positif. Dalam pemilihan metode dan strategi ini pendidik semestinya mempertimbangkan situasi, kondisi, dan sarana yang dimiliki oleh sekolah. Hal ini sangat penting karena pemilihan suatu metode pembelajaran mengandung konsekwensi yang sangat serius terhadap peserta didik.

\section{E. Cara Penelitian}

\section{Siklus I}

Dalam penelitian yang kami lakukan di SMP Muhammadiyah IV Yogyakarta, model delikan dapat diterapkan dalam pembelajaran IPS-Sejarah. Bahkan dapat disimpulkan bahwa penerapan model delikan dalam pembelajaran IPS-Sejarah dapat meningkatkan kualitas pembelajaran. Hal ini dapat kami lihat dari kualitas portofolio, proses belajar, dan daya tangkap siswa yang lebih baik.

Hal ini barangkali disebabkan oleh proses pembelajaran di SMP Muhammadiyah IV Yogyakarta telah didukung dengan sarana yang memadai. Misalnya tersedianya sumber belajar yang lengkap, tingkat kemampuan siswa yang cukup baik, dan sarana belajar yang memadai. SMP Muhammadiyah IV Yogyakarta juga telah memiliki sarana ICT untuk meningkatkan kualitas pembelajarannya sehingga hal ini memudahkan para siswa dan guru untuk mengakses internet sebagai sumber belajar.

Penerapan delikan dalam pembelajaran IPS-Sejarah di SMP Muhammadiyah IV Yogyakarta dapat kami gambarkan sebagai berikut:

${ }^{13}$ Freire, Paulo (1999), Politik Pendidikan: Kebudayaan, Kekuasaan dan Pembebasan (terj.) Yogyakarta: Pustaka Pelajar. Hlm. Ix.

${ }^{14}$ Soedjatmoko, Op. cit. hlm. 180. 
1. Kelas yang terdiri dari 40 siswa dibagi dalam 8 kelompok, sehingga masingmasing kelompok terdiri dari 5 orang siswa.

2. Guru memberikan informasi tentang materi pembelajaran, termasuk tugas yang harus dikerjakan secara berkelompok. Untuk tugas yang harus dikerjakan, dalam siklus I dipilih membuat makalah dengan tema yang sudah ditentukan (proses dengar). Dalam kesempatan tersebut guru kolaborator juga menunjukkan contoh makalah yang baik kepada tiap-tiap kelompok (proses lihat)

3. Kelompok kerja siswa diberikan waktu selama 1 minggu untuk mengumpulkan sumber belajar yang berkaitan dengan materi yang ditentukan. Penentuan materi belajar dapat dijabarkan sebagai berikut:

\begin{tabular}{|l|l|l|}
\hline No & \multicolumn{1}{|c|}{ Kelompok } & \multicolumn{1}{c|}{ Materi } \\
\hline 1 & P. Diponegoro & Bandung Lautan Api \\
\hline 2 & Cut Nya' Dien & Pertempuran 10 November di Surabaya \\
\hline 3 & KHA. Dahlan & Pertempuran Medan Area \\
\hline 4 & Imam Bonjol & Peristiwa Merah Putih 14 Februari 1946 \\
\hline 5 & KH Dewantara & Perjanjian Linggarjati \\
\hline 6 & Kahar Muzakir & Agresi Militer Belanda I \\
\hline 7 & Jend. Sudirman & Serangan Umum 1 Maret 1949 \\
\hline 8 & Kartini & PDRI \\
\hline
\end{tabular}

4. Setelah masing-masing kelompok mengetahui tugasnya masing-masing, maka mereka diberikan kebebasan untuk mengerjakan tugasnya di dalam kelas. Dalam hal ini siswa berdiskusi dalam kelompok-kelompok yang telah ditentukan. Point penting yang dapat kami tangkap dari diskusi mereka adalah adanya usaha dari siswa untuk mencari informasi dari sumber belajar. Mereka juga sharing dengan teman-temannya dalam kelompok tersebut, bahkan adan usaha saling melengkapi pengetahuan dan informasi.

5. Setelah siswa memperoleh pengetahuan yang memadai, mereka diminta membuat makalah (proses kerjakan). Di sini mereka membuktikan bahwa di samping memahami materi yang telah ditentukan mereka juga mampu mengolah pengetahuan yang diperoleh dan menuangkannya ke dalam bentuk makalah dengan kata-kata mereka sendiri.

Subjek penelitian ini adalah kelas IX SMP Muhammadiyah IV Yogyakarta. Pemilihan kelas IX didasarkan pada asumsi bahwa kelas tersebut telah memiliki kemampuan berfikir memadai. Mereka juga telah mempunyai tanggung jawab untuk menyelesaikan tugas yang diberikan oleh gurunya. 
Penilaian tim peneliti ternyata terbukti benar, karena pada umumnya siswa sangat appreciate dengan model pembelajaran yang diterapkan. Di dalam kelas siswa terlihat sangat antusias mempelajari materi pelajaran yang diberikan melalui berbagai sumber belajar.

Siswa mencari bahan untuk penyusunan makalah dari berbagai sumber antara lain buku di perpustakaan, majalah dan internet. Mereka terlihat sangat familiar dengan internet, karena memang sekolah menyediakan fasilitas tersebut. Penyusunan makalah dilakukan secara bersama-sama di dalam kelas. Mereka berdiskusi dengan temannya dalam satu kelompok untuk membahas masalah-masalah yang mereka hadapi. Dalam diskusi terlihat siswa mampu memberikan masukan yang cukup signifikan. Mereka juga terlihat saling melengkapi pengetahuan yang mereka peroleh.

\section{Siklus II}

Dalam siklus II tim peneliti memutuskan untuk memberikan tugas membuat komik sejarah. Membuat komik sejarah lebih kompleks bila dibandingkan dengan menyusun makalah karena dalam membuat komik diperlukan kemampuan untuk memahami peristiwa sejarah serta kemampuan berimajinasi dalam menuangkan peristiwa tersebut ke dalam bentuk cerita bergambar. Dalam membuat komik sejarah juga diperlukan kemampuan dan keahlian lain yaitu kemampuan melukis atau menggambar. Oleh karena itu tim peneliti melakukan pemetaan kemampuan siswa, sehingga setiap kelompok dipastikan ada seorang siswa yang mempunyai kemampuan melukis dengan baik.

Dalam mengimplementasikan model delikan, tim peneliti mengambil langkah-langkah sama seperti dalam siklus I. Pertama-tama guru kolaborator memberikan orientasi dan penjelasan mengenai tujuan pembelajaran serta tugas yang harus dilaksanakan oleh siswa (proses dengar). Dalam hal ini guru kolaborator juga membuka kesempatan kepada siswa untuk mengajukan pertanyaan-pertanyaan apabila merasa belum jelas dengan tugas yang akan dikerjakan. Pada umumnya siswa telah mengerti dan memahami tugas mereka masing-masing sehingga proses dengar dapat berjalan dengan lancar. Selanjutnya guru kolaborator menunjukkan contoh-contoh komik yang baik (proses lihat). Hal ini dilakukan dengan tujuan agar kerja siswa sesuai dengan tujuan yang telah ditetapkan, yakni memahami peristiwa sejarah dengan unjuk kerja. 
Tahap selanjutnya siswa diminta melaksanakan tugas dengan membuat komik (proses kerjakan). Proses pembuatan komik dilakukan di dalam jam pelajaran di kelas sehingga guru kolaborator dapat melihat dan mengamati proses pembuatan komik secara langsung. Dalam proses kerjakan terlihat bahwa siswa berusaha mengidentfikasi tokoh-tokoh sejarah berdasarkan persepsi masing-masing sehingga antara kelompok satu dan kelompok yang lain terdapat beberapa perbedaan dalam mengidentifikasi tokoh-tokoh sejarah.

Proses kerjakan berjalan selama dua minggu atau dua kali jam pelajaran, namun ternyata siswa belum dapat menyelesaikan tugasnya sehingga tim peneliti dan guru kolaborator memutuskan memberikan kesempatan kepada siswa untuk menyelesaikan tugas di luar jam pelajaran. Dengan demikian maka siswa menyelesaikan tugas tersebut di rumah dan di sekolah setelah jam pelajaran. Hal ini memberikan gambaran kepada kita bahwa siswa mempunyai motivasi yang amat tinggi untuk belajar. Barangkali proses pembelajaran dengan model delikan memberikan nuansa yang baru kepada siswa sehingga mereka mempunyai semangat untuk menyelesaikan tugas-tugas dari gurunya. Setelah diberi tambahan waktu selama seminggu, siswa berhasil menyelesaikan tugasnya dan dikumpulkan kepada guru kolaborator.

Dari evaluasi tim peneliti, siswa berhasil menyelesaikan pekerjaan mereka dengan cukup baik. Hal ini didasarkan pada penilaian terhadap hasil karya mereka yang secara umum sudah cukup baik. Penilaian ini didasarkan kepada beberapa kriteria antara lain:

1. Alur cerita

2. Skenario

3. Script

4. Identifikasi tokoh-tokoh sejarah baik yang protagonist maupun antagonis.

5. Setting (baik waktu maupun tempat)

Dengan kriteria tersebut maka tim peneliti dapat menentukan mana yang termasuk kategori amat baik, baik, cukup, dan kurang. Dari lima buah komik yang dihasilkan, hanya satu yang dianggap cukup, dua komik lainnya termasuk baik, sedangkan dua komik amat baik. Dilihat dari alur cerita, scenario, script, dan settingnya, seluruh komik menunjukkan bahwa pembuatnya menguasai materi dengan amat baik. Sementara itu identifikasi tokoh menurut tim peneliti dianggap kurang karena tokoh-tokoh sejarah diidentifikasi dengan pahlawan-pahlawan masa kini dengan aksesori pakaian dan penampilan yang kurang pas. Namun secara keseluruhan komik yang dihasilkan oleh siswa telah 
baik sehingga ini merepresentasikan keberhasilan model pembelajaran yang dilakukan oleh guru.

\section{F. Penutup}

Berdasarkan hasil penelitian tersebut, tim peneliti dapat mengambil kesimpulan bahwa dengan penerapan model delikan, pembelajaran IPS-Sejarah di SMP mengalami peningkatan yang signifikan. Pola pembelajaran yang bergerak dari strategi ekspository menuju inquiry yang melibatkan peranan guru dan siswa menghasilkan pola pembelajaran yang impresif, dialogis, dan bermakna bagi siswa. Ketika model delikan dipadu dengan metode diskusi maka terlihat siswa dapat mengambil peranan yang signifikan dalam upaya penguasaan materi pembelajaran.

Meskipun model delikan dianggap sebagai model pembelajaran yang konvensional, akan tetapi dengan beberapa inovasi ternyata model tersebut efektif dalam meningkatkan kualitas pembelajaran. Di mata siswa penerapan model delikan dalam mata pelajaran IPS-Sejarah menghasilkan pembelajaran yang menyenangkan, humanis, dan merdeka sehingga mereka dapat menikmati proses pembelajaran dengan perasaan senang, merdeka, dan bahagia. Hal ini menumbuhkan proses pembelajaran yang bermakna bagi siswa. Muara dari semua itu adalah adanya efektifitas proses pembalajaran IPS-Sejarah sehingga model delikan dapat dijadikan salah satu alternatif untuk meningkatkan kualitas pembelajaran.

\section{Daftar Pustaka}

Banathy, Bella H (1992), A System View of Education: Concepts and Principles for Effective Practice, Englewood Cliffs: Educational Technology Publication.

Beyer, Barry K. (1999), Inquiry in the Social Studies Clasroom Strategy for Teaching, Ohio: Charles Merry Publishing.

Elliot, John. (1991), Action Research For Educational Change, Milton Keynes, Philadelphia: Open University Press.

Freire, Paulo (1999), Politik Pendidikan: Kebudayaan, Kekuasaan dan Pembebasan (terj.) Yogyakarta: Pustaka Pelajar. 
Nasution, (2002), Mengajar Dengan Sukses, Yogyakarta: Bumi Aksara.

Soedjatmoko (1976), “Kesadaran Sejarah Dalam Pembangunan”, Prisma Edisi VII. Gunning, Dennis (1978), The Teaching of History, London: Cronhelm.

Soewarso (2000), Cara Penyampaian Pendidikan Sejarah Untuk Membangkitkan Minat Peserta Didik Mempelajari Sejarah Bangsanya, Jakarta: Dirjen Dikti Depdiknas.

Sri Anitah Wiryawan \& Nurhadi (2001), Strategi Belajar Mengajar, Jakarta: Pusat Penerbitan Universitas Terbuka.

Winata Putera (1992), Model-model Pembelajaran, Jakarta: Depdikbud.

\section{Tentang Penulis}

Aman, menyelesaikan S1 dari Jurusan Pendidikan Sejarah IKIP Yogyakarta pada tahun 1999. Sedangkan S2 pada program studi Pendidikan Sejarah Universitas Sebelas Maret Surakarta diselesaikan beberapa tahun kemudian. Saat ini sedang menyelesaikan pendidikan doktoralnya dalam bidang penelitian dan evaluasi pendidikan pada Universitas Negeri Yogyakarta. Mata kuliah yang diampu antara lain: Statistika, Sejarah Indonesia Abad XIX, dan Seminar Sejarah.

Grendy Hendrastomo, Menyelesaikan pendidikan S1 pada program studi Sosiologi Universitas Gajah Mada pada tahun 2004, sedangkan Gelar Magister Manajemen diperolehnya pada tahun 2007. Saat ini sedang menempuh pendidikan S2 pada program studi Sosiologi Universitas Gajah Mada Yogyakarta. Mata kuliah yang diampu antara lain: Sosiologi Hukum, Komputer, dan Dasar-dasar Sosiologi.

Sudrajat, salah satu dosen muda pada Jurusan Pendidikan Sejarah FISE Universitas Negeri Yogyakarta. Menyelesaikan pendidikan S1 pada program studi Pendidikan Sejarah IKIP Yogyakarta pada tahun 1999. Saat ini sedang menempuh pendidikan S2 pada program studi Pendidikan IPS di Universitas Negeri Yogyakarta. Mata kuliah yang diampu antara lain: Sejarah Eropa Lama, Sejarah Eropa Baru, Pengantar Sejarah Eropa, dan Sejarah Lisan. 